Article

\title{
Bioactive Steroids from the Red Sea Soft Coral Sinularia polydactyla
}

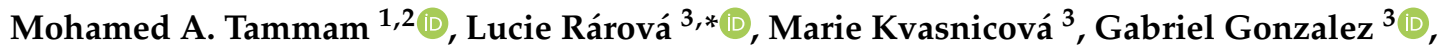 \\ Ahmed M. Emam ${ }^{2}$, Aldoushy Mahdy ${ }^{4}\left(\mathbb{D}\right.$, Miroslav Strnad ${ }^{3}$, Efstathia Ioannou ${ }^{1}(\mathbb{D}$ and \\ Vassilios Roussis 1,*(D) \\ 1 Section of Pharmacognosy and Chemistry of Natural Products, Department of Pharmacy, \\ National and Kapodistrian University of Athens, Panepistimiopolis Zografou, 15771 Athens, Greece; \\ mtammam@pharm.uoa.gr (M.A.T.); eioannou@pharm.uoa.gr (E.I.) \\ 2 Department of Biochemistry, Faculty of Agriculture, Fayoum University, Fayoum 63514, Egypt; \\ ame01@fayoum.edu.eg \\ 3 Laboratory of Growth Regulators, Institute of Experimental Botany, The Czech Academy of Sciences, \\ Faculty of Science, Palacký University, Šlechtitelů 27, CZ-78371 Olomouc, Czech Republic; \\ kvasnicova@ueb.cas.cz (M.K.); gonzalez.gabriel@seznam.cz (G.G.); miroslav.strnad@upol.cz (M.S.) \\ 4 Department of Zoology, Faculty of Science, Al-Azhar University (Assiut Branch), Assiut 71524, Egypt; \\ aldoushy@azhar.edu.eg \\ * Correspondence: lucie.rarova@upol.cz (L.R.); roussis@pharm.uoa.gr (V.R.); \\ Tel.: +420-5856-34698 (L.R.); +30-210-727-4592 (V.R.)
}

Received: 16 November 2020; Accepted: 8 December 2020; Published: 10 December 2020

\begin{abstract}
Six new $(1,2,6,8,13$, and 20) and twenty previously isolated (3-5, 7, 9-12, 14-19, and 21-26) steroids featuring thirteen different carbocycle motifs were isolated from the organic extract of the soft coral Sinularia polydactyla collected from the Hurghada reef in the Red Sea. The structures and the relative configurations of the isolated natural products have been determined based on extensive analysis of their NMR and MS data. The cytotoxic, anti-inflammatory, anti-angiogenic, and neuroprotective activity of compounds 3-7, 9-12, 14-20, and 22-26, as well as their effect on androgen receptor-regulated transcription was evaluated in vitro in human tumor and non-cancerous cells. Steroids 22 and $\mathbf{2 3}$ showed significant cytotoxicity in the low micromolar range against the HeLa and MCF7 cancer cell lines, while migration of endothelial cells was inhibited by compounds $11,12,22$, and 23 at $20 \mu \mathrm{M}$. The results of the androgen receptor (AR) reporter assay showed that compound 11 exhibited the strongest inhibition of AR at $10 \mu \mathrm{M}$, while it is noteworthy that steroids 10, 16, and 20 displayed increased inhibition of AR with decreasing concentrations. Additionally, compounds $\mathbf{1 1}$ and $\mathbf{2 3}$ showed neuroprotective activity on neuron-like SH-SY5Y cells.
\end{abstract}

Keywords: Sinularia polydactyla; soft coral; steroids; cytotoxic; anti-inflammatory; neuroprotective; androgen receptor

\section{Introduction}

The Red Sea, one of the warmest and most saline marine habitats, is an extension of the Indian Ocean, located between the Arabian Peninsula and Africa. The entire coastal reef complex extends along a 2000-km shoreline and is characterized by a high degree of chemodiversity, including more than 200 soft and 300 hard coral species [1]. Despite the diverse marine life hosted in the Red Sea, marine organisms from this ecosystem have not been thoroughly studied in comparison to other extended coral habitats, such as those encountered in the Great Barrier Reef or the Caribbean Sea [2]. 


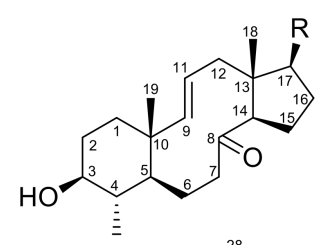

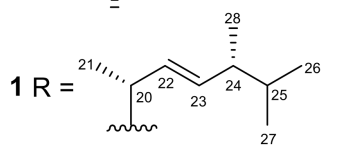

$2 \mathrm{R}=\left.\min _{211 \prime \prime 2}^{22} 23 \overbrace{24}^{28}\right|_{27} ^{26}$<smiles>[R]C1CCC2[C@@H]3CC[C@H]4[C@@H](C)[C@@H](O)CC[C@]4(C)[C@H]3CC[C@]12C</smiles>

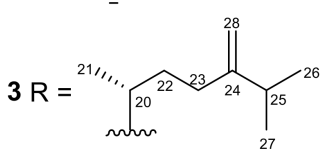

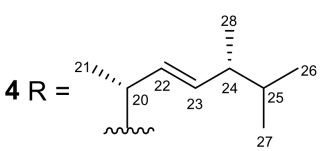<smiles>[R]C1CCC2C1(C)CCC1C2(C)CC[C@H]2[C@@H](C)[C@H](O)CC[C@@]12C</smiles>

$\mathbf{S} \mathrm{R}=\left.\left.{ }^{211 \ldots} \underbrace{22-23}_{20}\right|_{24} ^{28}\right|_{25} ^{26}$

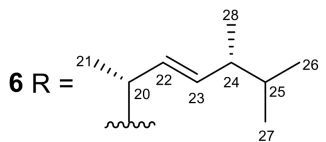

$7 \mathrm{R}={ }^{21 / \ldots}$

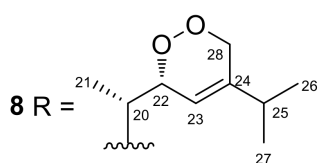

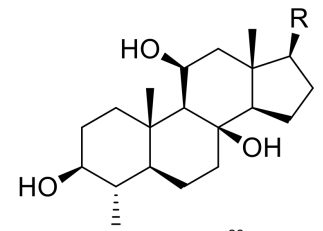

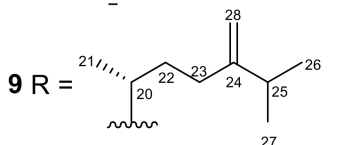

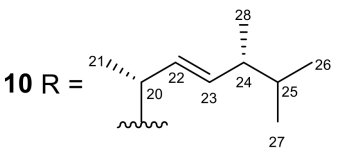<smiles>[R][Y][C@H](C)CC(=O)C(=C)C(C)C</smiles><smiles>[R2]C[C@@H](C)CC(OC(C)C)C(=C)C(C)C</smiles><smiles>[R3]C[C@@H](C)[C@H]1C=C(C(C)C)COO1</smiles>

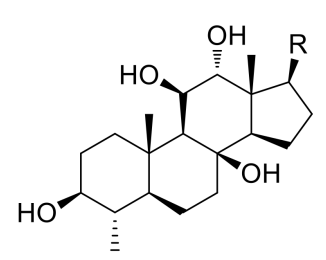<smiles>[R4]C[C@H](C)/C=C/[C@H](C)C(C)C</smiles><smiles>[R]C1CCC2[C@H]3CC[C@]4(C)[C@@H](C)[C@@H](O)CC[C@@]4(C)[C@H]3CC[C@]12O</smiles><smiles>[R5]C[C@@H](C)CCC(=C)C(C)C</smiles>

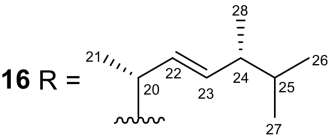<smiles>[R]C1CC[C@H]2[C@@H]3[C@H](O)C=C4C[C@@H](O)CC[C@]4(C)[C@H]3CC[C@]12C</smiles>

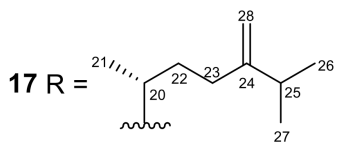<smiles>[R]C1CC[C@H]2[C@@H]3CC=C4C[C@@H](O)CC[C@]4(C)[C@H]3CC[C@]12C</smiles><smiles>[R]C1CC[C@H]2[C@H]3[C@H](OC(C)=O)C=C4C[C@H](O)CC[C@]4(CO)[C@H]3CC[C@@]12C</smiles>

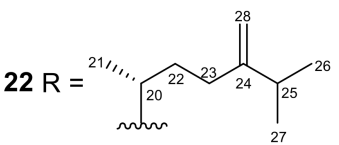<smiles>[R]C[C@@H](CCC)CCCCC(C)C</smiles><smiles>[R18][13CH2][C@@H](C)CCC(=C)C(C)C</smiles><smiles>[R]C1CC[C@H]2[C@@H]3C(=O)C=C4C[C@@H](O)CC[C@]4(CO)[C@H]3CC[C@]12C</smiles><smiles>[R]C1CC[C@H]2[C@@H]3CC=C4C[C@@H](O)CC[C@]4(CO)[C@H]3CC[C@]12C</smiles><smiles>[R4]C[C@H](C)CCC(=C)C(C)C</smiles><smiles>[R]C[C@H](CC)CCC(=C)C(C)C</smiles><smiles>[R]C[C@H](C)/C=C/C(=C)C(C)C</smiles><smiles>[R]C1CCC2C3=C[C@H](O)[C@@]4(O)C[C@@H](O)CC[C@]4(C)[C@H]3CC[C@]12C</smiles><smiles>[R]C[C@H](C)CCC(=C)C(C)C</smiles><smiles>[R]C1CCC2[C@@H]3[C@H](O)C=C4C[C@@H](O)CC[C@]4(CO)[C@H]3CC[C@]12C</smiles><smiles>[R]C[C@H](C)/C=C/[C@H](C)C(C)C</smiles>

Figure 1. Chemical structures of compounds 1-26.

Over the last 50 years, soft corals (Anthozoa, Gorgonacea) have been the subject of extensive chemical investigations which have resulted in the isolation of a large of number secondary metabolites, mainly sesquiterpenes, diterpenes, prostanoids, and highly functionalized steroids [3]. 
A significant number of these metabolites have exhibited potent biological properties, including cytotoxic, antibacterial, antifungal, anti-inflammatory, and antifouling activity [2]. Among soft corals, species of the genus Sinularia have been extensively studied as sources of new bioactive compounds, most often leading to the isolation of diterpenes and steroids with noteworthy levels of bioactivity $[2,3]$.

In the context of our continuous interest for the isolation of bioactive metabolites from marine organisms, we recently had the opportunity to collect specimens of Sinularia polydactyla from the coastline of Hurghada in the Red Sea (Egypt) and investigate its chemical profile. Herein we report the isolation, structure elucidation, and evaluation of biological activity of six new $(\mathbf{1}, \mathbf{2}, \mathbf{6}, \mathbf{8}, \mathbf{1 3}$, and 20) and twenty previously isolated (3-5, 7, 9-12, 14-19, and 21-26) steroids (Figure 1).

\section{Results and Discussion}

\subsection{Structure Elucidation of the Isolated Metabolites}

A series of normal- and reversed-phase chromatographic separations of the organic extract of the soft coral S. polydactyla collected from the Egyptian Red Sea coastline at Hurghada allowed for the isolation of compounds $\mathbf{1 - 2 6 .}$

Compound 1, isolated as a white amorphous solid, possessed the molecular formula $\mathrm{C}_{29} \mathrm{H}_{48} \mathrm{O}_{2}$, as indicated by the HR-APCIMS and NMR data. The ${ }^{13} \mathrm{C}$ NMR and HSQC-DEPT spectra revealed the presence of 29 carbon atoms, corresponding to seven methyls, seven methylenes, twelve methines, and three non-protonated carbon atoms. Among them, evident were one carbonyl resonating at $\delta_{C} 213.1$, four olefinic carbons resonating at $\delta_{C} 127.6,132.6,135.2$, and 142.0 and an oxygenated carbon resonating at $\delta_{\mathrm{C}} 76.6$. In the ${ }^{1} \mathrm{H}$ NMR spectrum evident were two methyls on non-protonated carbons $\left(\delta_{\mathrm{H}} 0.94\right.$ and 1.08), five methyls on tertiary carbons $\left(\delta_{\mathrm{H}} 0.80,0.81,0.89,0.99\right.$, and 1.04), one oxygenated methine $\left(\delta_{\mathrm{H}} 3.09\right)$, and four olefinic methines $\left(\delta_{\mathrm{H}} 5.15,5.20,5.28\right.$, and 5.41). Since the carbonyl moiety and the two carbon-carbon double bonds accounted for three of the six degrees of unsaturation, the molecular structure of $\mathbf{1}$ was determined as tricyclic. The spectroscopic features of metabolite 1 (Tables 1 and 2), in conjunction with the homonuclear and heteronuclear correlations observed in its HSQC, HMBC, and COSY spectra (Figure 2) suggested that compound 1 possessed a 8-oxo-3-hydroxy-4-methyl-8,9-seco steroidal nucleus with a $\Delta^{9,11}$ and $\mathrm{C}_{9} \mathrm{H}_{17}$ unsaturated side chain with a 1,2-disubstituted double bond between C-22 and C-23. Specifically, the correlations observed in the COSY spectrum identified three distinct spin systems, namely (a) a spin system starting from $\mathrm{H}-1$ to $\mathrm{H}_{2}-7$, incorporating $\mathrm{H}_{3}-29$ which was coupled to $\mathrm{H}-4$, (b) a short spin system from $\mathrm{H}-9$ to $\mathrm{H}_{2}-12$ through $\mathrm{H}-11$, and (c) an extended branched spin system from $\mathrm{H}-14$ to $\mathrm{H}_{3}-26$, including $\mathrm{H}_{3}-21$, $\mathrm{H}_{3}-27$, and $\mathrm{H}_{3}-28$ which were coupled to $\mathrm{H}-20, \mathrm{H}-25$, and $\mathrm{H}-24$, respectively. The HMBC correlations of $\mathrm{H}_{3}-19$ with $\mathrm{C}-1, \mathrm{C}-5, \mathrm{C}-9$, and $\mathrm{C}-10$ concluded the six-membered ring and positioned the first angular methyl on C-10, connecting at the same time spin systems (a) and (b). Additionally, the HMBC correlations of $\mathrm{H}_{3}-18$ with $\mathrm{C}-12, \mathrm{C}-13, \mathrm{C}-14$, and C-17 identified the five-membered ring and fixed the position of the second angular methyl on C-13, connecting spin systems (b) and (c). The HMBC correlations of $\mathrm{H}_{2}-6, \mathrm{H}_{2}-7$, and $\mathrm{H}-14$ with the carbonyl carbon $\mathrm{C}-8$ supported the cleavage of the $\mathrm{C}-8 / \mathrm{C}-9$ bond, giving rise to the decalin ring and connecting spin systems (a) and (c). The geometry of the two double bonds was determined as $E$ in both cases on the basis of the measured coupling constants $\left(J_{9,11}=15.3 \mathrm{~Hz}\right.$ and $\left.J_{22,23}=15.2 \mathrm{~Hz}\right)$. The enhancements of $\mathrm{H}-3 / \mathrm{H}-5, \mathrm{H}-3 / \mathrm{H}_{3}-29, \mathrm{H}-4 / \mathrm{H}_{3}-19$, H-5/H-9, H-9/H-12 $\alpha$, H-9/H-14, H-11/H-12 $3, \mathrm{H}-11 / \mathrm{H}_{3}-18, \mathrm{H}-11 / \mathrm{H}_{3}-19, \mathrm{H}-14 / \mathrm{H}-17$, and $\mathrm{H}_{3}-18 / \mathrm{H}-20$ observed in the NOESY spectrum (Figure 2) verified the trans fusion of the six-membered and the ten-membered rings, as well as the trans fusion of the latter with the five-membered ring and determined the relative configuration of the stereogenic centers. The $R$ configuration at $C-24$ was proposed on the basis of the $0.3 \mathrm{ppm}$ difference in the chemical shifts of C-26 and C-27 and the chemical shift of C-28 resonating at $17.6 \mathrm{ppm}$ [4]. On the basis of the above, metabolite $\mathbf{1}$ was identified as (9E,22E,24R)-3 $\beta$-hydroxy-4 $\alpha, 24$-dimethyl-8,9-seco-5 $\alpha$-cholesta-9(11),22-dien-8-one. 
Table 1. ${ }^{1} \mathrm{H}$ NMR data ( $\delta$ in ppm, $J$ in $\mathrm{Hz}$ ) in $\mathrm{CDCl}_{3}$ of compounds $1, \mathbf{2}, \mathbf{4}, \mathbf{6}, \mathbf{8}, \mathbf{1 3}$, and 20.

\begin{tabular}{|c|c|c|c|c|c|c|c|}
\hline Position & $1^{1}$ & $2^{1}$ & $4^{2}$ & $6^{2}$ & $8^{1}$ & $13^{1}$ & $20^{3}$ \\
\hline 1 & $1.33 \mathrm{~m}, 1.22 \mathrm{~m}$ & $1.36 \mathrm{~m}, 1.24 \mathrm{~m}$ & $1.71 \mathrm{~m}, 0.98 \mathrm{~m}$ & $1.72 \mathrm{~m}, 0.93 \mathrm{~m}$ & $1.72 \mathrm{~m}, 0.96 \mathrm{~m}$ & $1.91 \mathrm{~m}, 1.00 \mathrm{~m}$ & $1.91 \mathrm{~m}, 1.08 \mathrm{~m}$ \\
\hline 2 & 1.76 m, $1.48 \mathrm{~m}$ & $1.76 \mathrm{~m}, 1.49 \mathrm{~m}$ & 1.77 m, $1.46 \mathrm{~m}$ & 1.77 m, $1.52 \mathrm{~m}$ & 1.78 m, 1.52 m & 1.79 m, $1.58 \mathrm{~m}$ & $1.84 \mathrm{~m}, 1.40 \mathrm{~m}$ \\
\hline 3 & $3.09 \operatorname{td}(10.1,4.8)$ & $3.10 \mathrm{~m}$ & $3.06 \mathrm{td}(10.5,4.9)$ & $3.04 \operatorname{td}(10.2,4.9)$ & $3.06 \mathrm{td}(10.5,5.2)$ & $3.05 \mathrm{td}(10.8,5.0)$ & $3.56 \mathrm{~m}$ \\
\hline 4 & $1.27 \mathrm{~m}$ & $1.28 \mathrm{~m}$ & $1.27 \mathrm{~m}$ & $1.31 \mathrm{~m}$ & $1.33 \mathrm{~m}$ & $1.41 \mathrm{~m}$ & $2.37 \mathrm{~m}, 2.18 \mathrm{~m}$ \\
\hline 5 & $0.91 \mathrm{~m}$ & $0.92 \mathrm{~m}$ & $0.72 \mathrm{~m}$ & $0.68 \mathrm{td}(12.4,2.9)$ & $0.71 \mathrm{td}(12.2,2.2)$ & $0.69 \operatorname{td}(11.9,2.2)$ & - \\
\hline 6 & $1.66 \mathrm{~m}, 1.60 \mathrm{~m}$ & $1.66 \mathrm{~m}, 1.62 \mathrm{~m}$ & $1.64 \mathrm{~m}, 1.47 \mathrm{~m}$ & $1.50 \mathrm{~m}, 1.33 \mathrm{~m}$ & $1.53 \mathrm{~m}, 1.33 \mathrm{~m}$ & $1.56 \mathrm{~m}, 1.39 \mathrm{~m}$ & $5.73 \mathrm{~m}$ \\
\hline 7 & $2.29 \mathrm{~m}, 1.75 \mathrm{~m}$ & $2.48 \mathrm{~m}, 2.24 \mathrm{~m}$ & $1.69 \mathrm{~m}, 1.50 \mathrm{~m}$ & $1.63 \mathrm{~m}, 1.13 \mathrm{~m}$ & $1.64 \mathrm{~m}, 1.19 \mathrm{~m}$ & $1.71 \mathrm{~m}, 1.22 \mathrm{~m}$ & $2.01 \mathrm{~m}, 1.51 \mathrm{~m}$ \\
\hline 8 & - & - & $1.28 \mathrm{~m}$ & - & - & - & $1.82 \mathrm{~m}$ \\
\hline 9 & $5.28 \mathrm{~d}(15.3)$ & $5.27 \mathrm{~m}$ & $0.60 \mathrm{~m}$ & $0.80 \mathrm{~m}$ & $0.81 \mathrm{~m}$ & $0.88 \mathrm{~m}$ & $0.89 \mathrm{~m}$ \\
\hline 11 & $5.41 \mathrm{ddd}(15.3,11.1,3.8)$ & $5.41 \mathrm{~m}$ & $1.47 \mathrm{~m}, 1.00 \mathrm{~m}$ & $1.62 \mathrm{~m}, 1.49 \mathrm{~m}$ & $1.62 \mathrm{~m}, 1.48 \mathrm{~m}$ & $4.43 \mathrm{brd}(1.9)$ & $1.62 \mathrm{~m}, 1.53 \mathrm{~m}$ \\
\hline 12 & $2.47 \mathrm{~m}, 1.70 \mathrm{~m}$ & $2.50 \mathrm{~m}, 1.72 \mathrm{~m}$ & $1.92 \mathrm{~m}, 1.11 \mathrm{~m}$ & $1.95 \mathrm{~m}, 1.16 \mathrm{~m}$ & $1.93 \mathrm{~m}, 1.17 \mathrm{~m}$ & $2.23 \mathrm{~m}, 1.37 \mathrm{~m}$ & $2.01 \mathrm{~m}, 1.17 \mathrm{~m}$ \\
\hline 14 & $2.49 \mathrm{~m}$ & $2.50 \mathrm{~m}$ & $0.93 \mathrm{~m}$ & $1.18 \mathrm{~m}$ & $1.23 \mathrm{~m}$ & $1.27 \mathrm{~m}$ & $0.90 \mathrm{~m}$ \\
\hline 15 & $1.64 \mathrm{~m}, 1.48 \mathrm{~m}$ & $1.64 \mathrm{~m}, 1.50 \mathrm{~m}$ & $1.51 \mathrm{~m}, 1.02 \mathrm{~m}$ & $1.45 \mathrm{~m}, 1.23 \mathrm{~m}$ & $1.53 \mathrm{~m}, 1.33 \mathrm{~m}$ & $1.60 \mathrm{~m}, 1.46 \mathrm{~m}$ & $1.50 \mathrm{~m}, 1.05 \mathrm{~m}$ \\
\hline 16 & $1.70 \mathrm{~m}, 1.47 \mathrm{~m}$ & $1.73 \mathrm{~m}, 1.49 \mathrm{~m}$ & $1.63 \mathrm{~m}, 1.19 \mathrm{~m}$ & $1.64 \mathrm{~m}, 1.23 \mathrm{~m}$ & $1.99 \mathrm{~m}, 1.31 \mathrm{~m}$ & $2.00 \mathrm{~m}, 1.35 \mathrm{~m}$ & $1.64 \mathrm{~m}, 1.26 \mathrm{~m}$ \\
\hline 17 & $1.31 \mathrm{~m}$ & $1.28 \mathrm{~m}$ & $1.09 \mathrm{~m}$ & $1.03 \mathrm{~m}$ & $1.43 \mathrm{~m}$ & $1.43 \mathrm{~m}$ & $1.18 \mathrm{~m}$ \\
\hline 18 & $1.08 \mathrm{~s}$ & $1.09 \mathrm{~s}$ & $0.64 \mathrm{~s}$ & $0.92 \mathrm{~s}$ & $0.89 \mathrm{~s}$ & $1.09 \mathrm{~s}$ & $0.75 \mathrm{~s}$ \\
\hline 19 & $0.94 \mathrm{~s}$ & $0.94 \mathrm{~s}$ & $0.80 \mathrm{~s}$ & $0.97 \mathrm{~s}$ & $0.96 \mathrm{~s}$ & $1.33 \mathrm{~s}$ & $3.81 \mathrm{~d}(11.5), 3.59 \mathrm{~d}(11.5)$ \\
\hline 20 & $2.10 \mathrm{~m}$ & $2.11 \mathrm{~m}$ & $1.98 \mathrm{~m}$ & $1.96 \mathrm{~m}$ & $1.56 \mathrm{~m}$ & $1.59 \mathrm{~m}$ & $2.11 \mathrm{~m}$ \\
\hline 21 & $0.99 \mathrm{~d}(6.8)$ & $0.93 \mathrm{~d}(6.1)$ & $0.97 \mathrm{~d}(6.6)$ & $0.94 \mathrm{~d}(6.4)$ & $0.83 \mathrm{~d}(6.9)$ & $0.85 \mathrm{~d}(7.0)$ & $1.03 \mathrm{~d}(6.5)$ \\
\hline 22 & $5.15 \mathrm{dd}(15.2,8.1)$ & $1.53 \mathrm{~m}, 1.14 \mathrm{~m}$ & $5.12 \mathrm{dd}(15.1,7.6)$ & $5.09 \mathrm{dd}(15.2,8.2)$ & 4.72 brs & 4.70 brs & $5.56 \mathrm{dd}(15.7,8.7)$ \\
\hline 23 & $5.20 \mathrm{dd}(15.2,7.3)$ & $2.08 \mathrm{~m}, 1.88 \mathrm{~m}$ & $5.17 \mathrm{dd}(15.1,7.0)$ & $5.16 \mathrm{dd}(15.2,7.4)$ & $5.36 \mathrm{brs}$ & $5.36 \mathrm{brs}$ & $5.92 \mathrm{~d}(15.7)$ \\
\hline 24 & $1.83 \mathrm{~m}$ & - & $1.83 \mathrm{~m}$ & $1.80 \mathrm{~m}$ & - & - & - \\
\hline 25 & $1.44 \mathrm{~m}$ & $2.21 \mathrm{~m}$ & $1.44 \mathrm{~m}$ & $1.42 \mathrm{~m}$ & 2.24 septet $(6.9)$ & 2.24 septet $(6.9)$ & 2.53 septet $(6.8)$ \\
\hline 26 & $0.81 \mathrm{~d}(6.8)$ & $1.00 \mathrm{~d}(6.8)$ & $0.81 \mathrm{~d}(6.8)$ & $0.81 \mathrm{~d}(6.8)$ & $1.05 \mathrm{~d}(6.9)$ & $1.05 \mathrm{~d}(6.9)$ & $1.06 \mathrm{~d}(6.8)$ \\
\hline 27 & $0.80 \mathrm{~d}(6.8)$ & $1.01 \mathrm{~d}(6.9)$ & $0.79 \mathrm{~d}(6.8)$ & $0.79 \mathrm{~d}(6.8)$ & $1.05 \mathrm{~d}(6.9)$ & $1.06 \mathrm{~d}(6.9)$ & $1.04 \mathrm{~d}(6.8)$ \\
\hline 28 & $0.89 \mathrm{~d}(6.8)$ & $4.70 \mathrm{brs}, 4.63 \mathrm{brs}$ & $0.88 \mathrm{~d}(6.8)$ & $0.88 \mathrm{~d}(6.8)$ & $4.62 \mathrm{~d}(15.7), 4.20 \mathrm{~d}(15.7)$ & $4.59 \mathrm{~d}(15.7), 4.21 \mathrm{~d}(15.7)$ & $4.83 \mathrm{brs}, 4.79 \mathrm{brs}$ \\
\hline 29 & $1.04 \mathrm{~d}(6.1)$ & $1.04 \mathrm{~d}(6.1)$ & $0.92 \mathrm{~d}(6.3)$ & $0.95 \mathrm{~d}(6.8)$ & $0.95 \mathrm{~d}(6.4)$ & $0.96 \mathrm{~d}(6.4)$ & - \\
\hline
\end{tabular}

${ }^{1}$ Recorded at $600 \mathrm{MHz} .{ }^{2}$ Recorded at $400 \mathrm{MHz} .{ }^{3}$ Recorded at $950 \mathrm{MHz},-$ absence of value. 
Table 2. ${ }^{13} \mathrm{C}$ NMR data ( $\delta$ in ppm) in $\mathrm{CDCl}_{3}$ of compounds $\mathbf{1}, \mathbf{4}, \mathbf{6}, \mathbf{8}, \mathbf{1 3}$, and 20.

\begin{tabular}{|c|c|c|c|c|c|c|}
\hline Position & $1^{1,2}$ & $4^{3}$ & $6^{1,4}$ & $8^{1,2}$ & $13^{2}$ & $20^{1,5}$ \\
\hline 1 & 38.5 & 36.8 & 37.7 & 37.2 & 37.5 & 32.9 \\
\hline 2 & 30.7 & 31.1 & 30.9 & 30.3 & 30.2 & 31.7 \\
\hline 3 & 76.6 & 76.6 & 76.8 & 76.4 & 76.5 & 70.8 \\
\hline 4 & 39.8 & 39.2 & 39.0 & 38.5 & 38.2 & 41.9 \\
\hline 5 & 53.5 & 51.0 & 51.9 & 51.2 & 52.3 & 134.9 \\
\hline 6 & 20.0 & 24.2 & 20.5 & 19.8 & 20.0 & 126.8 \\
\hline 7 & 47.1 & 32.2 & 40.1 & 39.6 & 39.9 & 30.8 \\
\hline 8 & 213.1 & 36.0 & 73.6 & 73.5 & 75.3 & 33.4 \\
\hline 9 & 142.0 & 54.6 & 56.6 & 56.0 & 57.6 & 49.9 \\
\hline 10 & 39.1 & 34.9 & 36.9 & 36.3 & 36.8 & 41.0 \\
\hline 11 & 127.6 & 21.1 & 18.3 & 18.1 & 69.8 & 21.4 \\
\hline 12 & 46.8 & 40.2 & 41.6 & 40.5 & 49.0 & 39.6 \\
\hline 13 & 55.2 & 42.4 & 43.0 & 42.7 & 41.8 & 42.3 \\
\hline 14 & 62.7 & 56.6 & 59.7 & 59.0 & 60.2 & 57.5 \\
\hline 15 & 26.6 & 24.2 & 19.0 & 18.7 & 19.2 & 24.1 \\
\hline 16 & 28.4 & 28.6 & 28.3 & 27.0 & 26.9 & 28.1 \\
\hline 17 & 56.7 & 56.1 & 57.1 & 52.4 & 53.9 & 55.4 \\
\hline 18 & 13.5 & 12.3 & 14.0 & 12.8 & 15.0 & 12.0 \\
\hline 19 & 15.8 & 13.4 & 13.8 & 13.2 & 15.6 & 62.3 \\
\hline 20 & 39.1 & 40.0 & 39.6 & 39.8 & 40.0 & 39.9 \\
\hline 21 & 21.7 & 20.9 & 21.3 & 12.8 & 12.9 & 20.2 \\
\hline 22 & 135.2 & 135.9 & 135.7 & 79.9 & 79.7 & 135.4 \\
\hline 23 & 132.6 & 131.6 & 131.8 & 119.4 & 119.2 & 128.8 \\
\hline 24 & 43.0 & 42.8 & 43.2 & 142.0 & 142.0 & 153.0 \\
\hline 25 & 33.2 & 33.1 & 33.8 & 30.8 & 31.1 & 28.8 \\
\hline 26 & 19.8 & 19.6 & 19.9 & 21.0 & 21.1 & 21.7 \\
\hline 27 & 20.1 & 19.9 & 20.2 & 21.0 & 21.1 & 22.1 \\
\hline 28 & 17.6 & 17.6 & 18.0 & 70.6 & 70.8 & 109.0 \\
\hline 29 & 16.4 & 15.1 & 16.0 & 14.9 & 15.2 & \\
\hline
\end{tabular}

${ }^{1}$ Chemical shifts were determined through HMBC correlations. ${ }^{2}$ Recorded at $150 \mathrm{MHz} .{ }^{3}$ Recorded at $50 \mathrm{MHz}$.

${ }^{4}$ Recorded at $100 \mathrm{MHz} .{ }^{5}$ Recorded at $237.5 \mathrm{MHz}$.

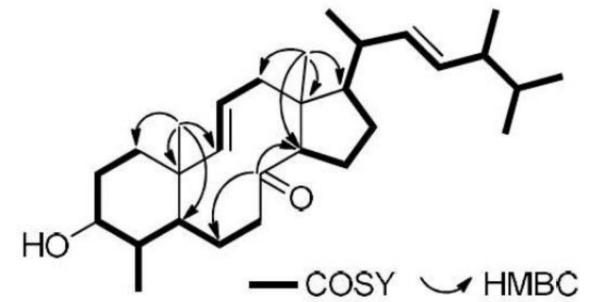

(a)

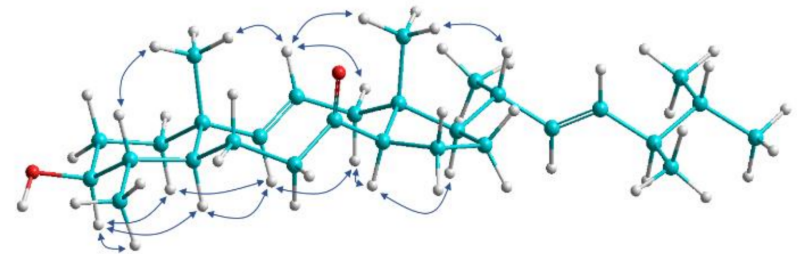

(b)

Figure 2. (a) COSY and key HMBC correlations and (b) key NOESY cross-peaks for compound 1.

Compound 2, isolated in minute amount as a white amorphous solid, displayed an ion peak at $\mathrm{m} / \mathrm{z}$ 429.3725 (HR-APCIMS), corresponding to $\mathrm{C}_{29} \mathrm{H}_{49} \mathrm{O}_{2}$ and consistent for $[\mathrm{M}+\mathrm{H}]^{+}$. Compound 2 shared quite similar spectroscopic features with 1 . In particular, all signals attributed to the steroidal nucleus, with the most prominent being the signals of the two angular methyls $\mathrm{H}_{3}-18$ and $\mathrm{H}_{3}-19\left(\delta_{\mathrm{H}} 1.09\right.$ and 0.94 , respectively), the methyl at $\mathrm{C}-4\left(\delta_{\mathrm{H}} 1.04\right)$, the oxymethine $\mathrm{H}-3\left(\delta_{\mathrm{H}} 3.10\right)$, and the two olefinic protons $\mathrm{H}-9$ and $\mathrm{H}-11\left(\delta_{\mathrm{H}} 5.27\right.$ and 5.41, respectively), were also evident in the ${ }^{1} \mathrm{H}$ NMR spectrum of compound 2 (Table 1). The most significant difference observed was the replacement of the 1,2-disubstituted double bond in the side chain of 1 by a 1,1-disustituted double bond $\left(\delta_{\mathrm{H}} 4.63\right.$ and 4.70$)$ in the side chain of $\mathbf{2}$. The correlations observed in the COSY spectrum of $\mathbf{2}$ identified the relevant spin systems; however, metabolite 2 was proven unstable and degraded prior to the acquisition of heteronuclear NMR 
spectra. Nevertheless, the high structural similarity of $\mathbf{2}$ with compound $\mathbf{1}$ renders safe the proposed identification of 2 as (9E)-3 $\beta$-hydroxy-4 $\alpha, 24$-dimethyl-8,9-seco-5 $\alpha$-cholesta-9(11),24(28)-dien-8-one.

Compound 6, isolated as a white amorphous solid, possessed the molecular formula $\mathrm{C}_{29} \mathrm{H}_{50} \mathrm{O}_{2}$, as suggested by its HR-APCIMS and NMR data. The spectroscopic data of 6 were quite similar to those of the previously reported metabolites 5 and 7 (Tables 1 and 2). The presence of the two angular methyls at $\delta_{\mathrm{H}} 0.92$ and 0.97 , the doublet methyl at $\delta_{\mathrm{H}} 0.95$, the oxygenated methine at $\delta_{\mathrm{H}} 3.04$ and the quaternary oxygenated carbon at $\delta_{\mathrm{C}} 73.6$, in conjunction with the correlations observed in the HMBC and COSY spectra (Figure 3a), verified the 3,8-dihydroxy-4-methyl steroidal nucleus. The side chain of compound 6 included four doublet methyls $\left(\delta_{\mathrm{H} / \mathrm{C}} 0.79 / 20.2,0.81 / 19.9,0.88 / 18.0\right.$, and 0.95/16.0) and two olefinic methines $\left(\delta_{\mathrm{H} / \mathrm{C}} 5.09 / 135.7\right.$ and 5.16/131.8) that was assigned on the basis of the COSY and HMBC correlations. The $E$ geometry of the $\Delta^{22}$ double bond was supported by the large coupling constant of $\mathrm{H}-22 / \mathrm{H}-23(\mathrm{~J}=15.3 \mathrm{~Hz})$. The enhancements of $\mathrm{H}-3 / \mathrm{H}-5, \mathrm{H}-3 / \mathrm{H}_{3}-29, \mathrm{H}-4 / \mathrm{H}_{3}-19, \mathrm{H}-5 / \mathrm{H}-9$, $\mathrm{H}-5 / \mathrm{H}_{3}-29, \mathrm{H}-9 / \mathrm{H}-12 \alpha, \mathrm{H}-9 / \mathrm{H}-14, \mathrm{H}-12 \beta / \mathrm{H}_{3}-18$, and $\mathrm{H}_{3}-18 / \mathrm{H}-20$ observed in the NOESY spectrum verified the trans fusion of rings $A / B, B / C$, and $C / D$ and suggested the axial orientation of the hydroxy group at $C-8$. The configuration at $C-24$ was proposed as $R$ due to the fact that the difference in the chemical shifts of C-26 and C-27 was $0.3 \mathrm{ppm}$ and that C-28 resonated at $18.0 \mathrm{ppm}$ [4]. Therefore, compound 6 was identified as $(22 E, 24 R)-4 \alpha, 24$-dimethyl- $5 \alpha$-cholest-22-en-3 $\beta, 8 \beta$-diol.

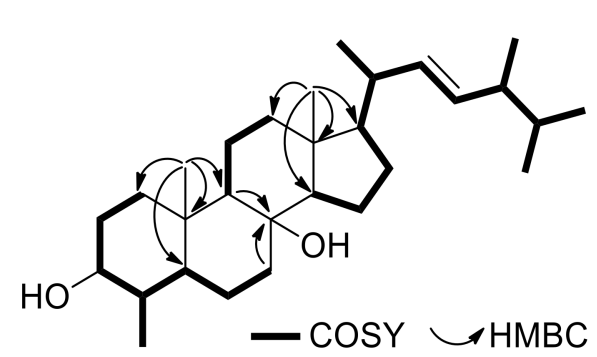

(a)

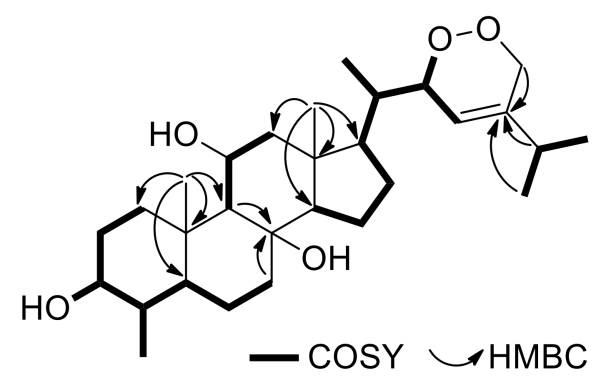

(c)

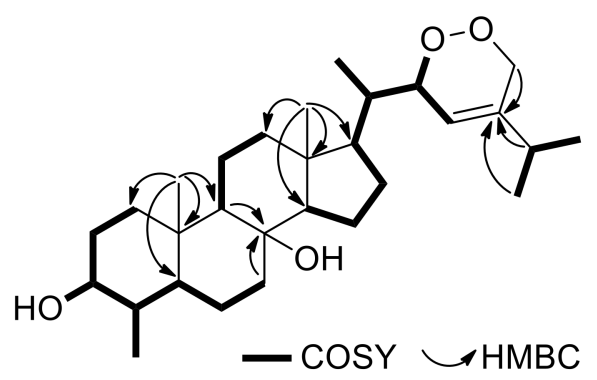

(b)

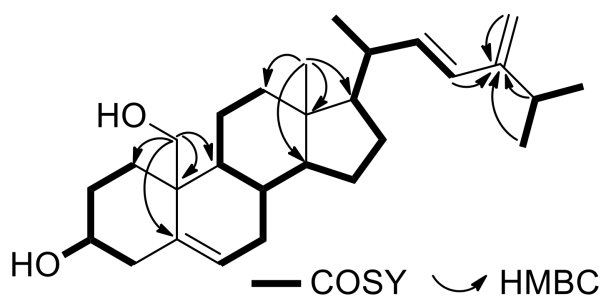

(d)

Figure 3. (a) COSY and important HMBC correlations for compound 6. (b) COSY and important HMBC correlations for compound 8. (c) COSY and important HMBC correlations for compound 13.

(d) COSY and important HMBC correlations for compound 20.

Compound 8, isolated as a white amorphous solid, exhibited an ion peak at $\mathrm{m} / \mathrm{z} 459.3475$ corresponding to $\mathrm{C}_{29} \mathrm{H}_{47} \mathrm{O}_{4}$ and consistent with $[\mathrm{M}-\mathrm{H}]^{-}$. The high degree of similarity of the spectroscopic data of metabolite 8 (Tables 1 and 2) with those of 5-7 indicated the same 3,8-dihydroxy-4-methyl steroidal nucleus, further confirmed by the correlations observed in the HMBC and COSY spectra (Figure 3b). Taking into account that the steroidal nucleus of 8 accounts for four of the six degrees of unsaturation and the presence of one double bond on the side chain, the latter 
should also contain an additional ring. The ${ }^{1} \mathrm{H}$ and ${ }^{13} \mathrm{C}$ NMR signals corresponding to the side chain of compound 8 included three doublet methyls $\left(\delta_{\mathrm{H} / \mathrm{C}} 0.95 / 14.9,1.05 / 21.0\right.$, and 1.05/21.0), one oxygenated methine $\left(\delta_{\mathrm{H} / \mathrm{C}} 4.72 / 79.9\right)$, one oxygenated methylene $\left(\delta_{\mathrm{H} / \mathrm{C}} 4.20,4.62 / 70.6\right)$, one olefinic methine $\left(\delta_{\mathrm{H} / \mathrm{C}}\right.$ 5.36/119.4), and one non-protonated olefinic carbon $\left(\delta_{C}\right.$ 142.0). The COSY cross-peaks of $\mathrm{H}-20 / \mathrm{H}_{3}-21$, $\mathrm{H}-20 / \mathrm{H}-22, \mathrm{H}-22 / \mathrm{H}-23, \mathrm{H}-25 / \mathrm{H}_{3}-26$, and $\mathrm{H}-25 / \mathrm{H}_{3}-27$, in combination with the HMBC correlations of $\mathrm{H}_{3}-21$ with $\mathrm{C}-17, \mathrm{C}-20$, and $\mathrm{C}-22$, of $\mathrm{H}-23, \mathrm{H}-25, \mathrm{H}_{3}-26$, and $\mathrm{H}_{3}-27$ with $\mathrm{C}-24$ and of $\mathrm{H}_{2}-28$ with C-23, C-24, and C-25 verified the side chain. In accordance with the literature, $\mathrm{H}-22$ was assigned to be on the opposite side of $\mathrm{H}_{3}-21$, as also suggested by the chemical shift of C-23 which resonated at 119.4 ppm. Instead, when $\mathrm{H}-22$ and $\mathrm{H}_{3}-21$ are co-planar, C-23 is shielded, resonating at 115-116 ppm [5]. Thus, metabolite 8 was identified as (23E)-22 $\alpha, 28$-epidioxy- $4 \alpha, 24$-dimethyl- $5 \alpha$-cholest-23-en-3 $\beta, 8 \beta$-diol.

Compound 13 was isolated as a white amorphous solid. The ion peak at $m / z 475.3424$ observed in its HR-APCIMS was consistent with $[\mathrm{M}-\mathrm{H}]^{-}$, dictating the molecular formula $\mathrm{C}_{29} \mathrm{H}_{48} \mathrm{O}_{5}$. The spectroscopic data of metabolite $\mathbf{1 3}$ related to the steroidal nucleus (Tables 1 and 2) displayed high similarity with those of 9-12, suggesting a 3,8,11-trihydroxy-4-methyl steroidal nucleus that was further verified by the correlations observed in the COSY, HMBC and NOESY spectra (Figure 3c). Additionally, the NMR data concerning the side chain of compound $\mathbf{1 3}$ were rather similar to those of $\mathbf{8}$, thus allowing for the identification of $\mathbf{1 3}$ as (23E)-22 $\alpha$,28-epidioxy- $4 \alpha, 24$-dimethyl- $5 \alpha$-cholest-23-en-3 $\beta, 8 \beta, 11 \beta$-triol.

Compound 20, isolated as a white amorphous solid, had the molecular formula $\mathrm{C}_{28} \mathrm{H}_{44} \mathrm{O}_{2}$, as indicated by its HR-ESIMS and NMR data. In the ${ }^{1} \mathrm{H}$ NMR spectrum of metabolite 20 evident were only one methyl on a non-protonated carbon $\left(\delta_{\mathrm{H}} 0.75\right)$, three methyls on tertiary carbons $\left(\delta_{\mathrm{H}} 1.03\right.$, 1.04 and 1.06), one hydroxymethylene $\left(\delta_{\mathrm{H}} 3.59\right.$ and 3.81), one oxygenated methine $\left(\delta_{\mathrm{H}} 3.56\right)$, three olefinic methines $\left(\delta_{\mathrm{H}} 5.56,5.73\right.$ and 5.92) and an exomethylene group $\left(\delta_{\mathrm{H}} 4.79\right.$ and 4.83$)$. The spectroscopic data of 20 (Tables 1 and 2) closely resembled those of the co-occurring 19, with the main difference being the presence of an additional 1,2-disubstituted double bond in the side chain of 20. The homonuclear and heteronuclear correlations observed in the COSY, HMBC, and NOESY spectra (Figure 3d) verified the 3,19-dihydroxy steroidal nucleus with a $\Delta^{5}$ double bond and the proposed side chain, as well as the relative configuration of the stereogenic centers. The $E$ geometry of the $\Delta^{22}$ double bond was assigned on the basis of the measured coupling constant between $\mathrm{H}-22$ and $\mathrm{H}-23(\mathrm{~J}=15.7 \mathrm{~Hz})$. On the basis of the above, metabolite 20 was identified as (22E)-24-methyl-cholesta-5,22,24(28)-trien-3 $\beta, 19$-diol.

Compounds 3, 5, 7, 9-12, 14-19, and 21-26 were identified by comparison of their spectroscopic and physical characteristics with those reported in the literature as $4 \alpha$,24-dimethyl-5 $\alpha$-cholest-24(28)-en$3 \beta$-ol (3) [6], (22E,24R)-4 $\alpha$,24-dimethyl-5 $\alpha$-cholest-22-en-3 $\beta$-ol (4) [7], 4 $\alpha$,24-dimethyl-5 $\alpha$-cholest-24(28)en-3 $\beta, 8 \beta$-diol (5) [8], 23-oxo- $4 \alpha$,24-dimethyl-5 $\alpha$-cholest-24(28)-en-3 $\beta, 8 \beta$-diol (7) [9], nebrosteroid $\mathrm{M}$ ( $4 \alpha, 24$ - dimethyl-5 $\alpha$-cholest-24(28)-en-3 $\beta, 8 \beta, 11 \beta$-triol, (9) [10], (22E,24R)-4 $\alpha$,24-dimethyl-5 $\alpha$-cholest-22en-3 $\beta, 8 \beta, 11 \beta$-triol (10) [4], nebrosteroid A (23-oxo- $4 \alpha, 24$-dimethyl-5 $\alpha$-cholest-24(28)-en-3 $\beta, 8 \beta, 11 \beta$-triol,

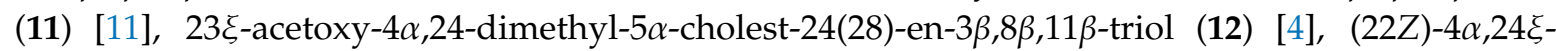
dimethyl-5 $\alpha$-cholest-22-en-3 $\beta, 8 \beta, 11 \beta, 12 \alpha$-tetraol (14) [4], $4 \alpha, 24$-dimethyl-5 $\alpha$-cholest-24(28)-en-3 $\beta, 8 \beta$, 18-triol (15) [4], (22E,24R)-4 $\alpha, 24$-dimethyl-5 $\alpha$-cholest-22-en-3 $\beta, 8 \beta, 18$-triol (16) [4], 24-methyl-cholesta5,24(28)-dien-3 $\beta$-ol (17) [12], 24-methyl-cholesta-5,24(28)-dien-3 $\beta, 7 \beta$-diol (18) [13], 24-methyl-cholesta5,24(28)-dien-3 $\beta$,19-diol (19) [14], 24-methyl-cholesta-5,24(28)-dien-3 $\beta, 7 \beta$,19-triol (21) [15], 7 $\beta$-acetoxy24-methyl-cholesta-5,24(28)-dien-3 $\beta, 19$-diol (22) [16], 7 $\beta$-acetoxy-cholest-5-en-3 $\beta, 19-d i o l ~(23)$ [15], 7-oxo24-methyl-cholesta-5,24(28)-dien-3 $\beta, 19$-diol (24) [17], 24-methyl-cholesta-7,24(28)-dien-3 $\beta, 5 \alpha, 6 \beta$-triol (25) [18], and (22E,24R)-24-methyl-cholesta-7,22-dien-3 $\beta, 5 \alpha, 6 \beta$-triol (26) [18], previously isolated from various marine organisms, mainly soft corals of the genera Litophyton and Nephthea. Even though compound 4 has been isolated in the past, only a few characteristic ${ }^{1} \mathrm{H}$ NMR resonances have been reported. Analysis of its $1 \mathrm{D}$ and $2 \mathrm{D}$ spectra allowed for the full assignment of the ${ }^{1} \mathrm{H}$ and ${ }^{13} \mathrm{C}$ chemical shifts of compound 4 (Tables 1 and 2). 


\subsection{Evaluation of the Biological Activity of the Isolated Metabolites}

Compounds 3-7, 9-12, 14-20, and 22-26, which were isolated in sufficient amounts, were evaluated in vitro in human tumor and non-cancerous cell lines for a number of biological activities, including cytotoxicity, anti-inflammatory, anti-angiogenic, and neuroprotective activity, as well as for their effect on androgen receptor (AR)-regulated transcription.

Initially, the cytotoxic activity of metabolites 3-7, 9-12, 14-20, and 22-26 was evaluated in human cancer and normal cells after $72 \mathrm{~h}$ of treatment. Human cervical cancer (HeLa), human breast adenocarcinoma (MCF7) cell lines, and human normal fibroblasts (BJ) were used for the screening. Among the tested compounds, 22 and 23 strongly reduced the viability of cancer cells in the low micromolar range (Table 3), compounds 9-12, 14-16, 18, and 24 showed moderate cytotoxic activity, while the remaining ten steroids were proven inactive. Most of the compounds with activity against cancer cells also showed cytotoxicity toward normal cells (BJ), except for compounds 11, 12, 14, 15, and 18. Compared to cisplatin, these compounds exhibit a wide therapeutic window because of the absence of cytotoxicity on normal human fibroblasts. Moreover, metabolite $\mathbf{2 2}$ was proven more active against the HeLa cell line than the reference standard cisplatin.

Table 3. Cytotoxicity $\left(\mathrm{IC}_{50} ; \mu \mathrm{M}\right)$ of compounds 3-7, 9-12, 14-20, and 22-26 against human cancer cell lines and fibroblasts after $72 \mathrm{~h}$ of treatment. Cisplatin was used as a positive control.

\begin{tabular}{cccc}
\hline Compound & HeLa & MCF7 & BJ \\
\hline $\mathbf{3}$ & $>50$ & $>50$ & $>50$ \\
$\mathbf{4}$ & $>50$ & $>50$ & $>50$ \\
$\mathbf{5}$ & $>50$ & $>50$ & $>50$ \\
$\mathbf{6}$ & $>50$ & $>50$ & $>50$ \\
$\mathbf{7}$ & $>50$ & $>50$ & $>50$ \\
$\mathbf{9}$ & $25.9 \pm 4.9$ & $36.4 \pm 5.7$ & $18.3 \pm 4.0$ \\
$\mathbf{1 0}$ & $32.9 \pm 6.8$ & $32.7 \pm 1.3$ & $4.1 \pm 1.9$ \\
$\mathbf{1 1}$ & $18.8 \pm 6.4$ & $21.7 \pm 1.4$ & $>50$ \\
$\mathbf{1 2}$ & $15.7 \pm 2.0$ & $25.3 \pm 6.5$ & $>50$ \\
$\mathbf{1 4}$ & $>50$ & $29.1 \pm 5.0$ & $>50$ \\
$\mathbf{1 5}$ & $19.0 \pm 4.3$ & $18.9 \pm 0.1$ & $>50$ \\
$\mathbf{1 6}$ & $32.9 \pm 5.2$ & $33.8 \pm 1.0$ & $23.2 \pm 1.4$ \\
$\mathbf{1 7}$ & $>50$ & $>50$ & $>50$ \\
$\mathbf{1 8}$ & $22.6 \pm 0.4$ & $28.6 \pm 5.3$ & $>50$ \\
$\mathbf{1 9}$ & $>50$ & $>50$ & $>50$ \\
$\mathbf{2 0}$ & $>50$ & $>50$ & $>50$ \\
$\mathbf{2 2}$ & $7.5 \pm 0.1$ & $8.9 \pm 0.0$ & $14.8 \pm 5.8$ \\
$\mathbf{2 3}$ & $12.0 \pm 1.7$ & $11.2 \pm 0.5$ & $14.5 \pm 3.9$ \\
$\mathbf{2 4}$ & $21.4 \pm 2.0$ & $31.7 \pm 0.3$ & $45.9 \pm 2.8$ \\
$\mathbf{2 5}$ & $>50$ & $>50$ & $>50$ \\
$\mathbf{2 6}$ & $>50$ & $>50$ & $>50$ \\
cisplatin & $11.4 \pm 3.8$ & $7.7 \pm 1.7$ & $6.9 \pm 0.9$ \\
\hline
\end{tabular}

Subsequently, we examined whether the isolated steroids could influence angiogenesis or inflammation in vitro. Compounds 3-7, 9-12, 14-20, and 22-26 and 2-methoxy-estradiol, which is known as an anti-angiogenic drug for the treatment of tumors and was used herein as positive control [19], were tested in the migration scratch and the tube formation assays using human umbilical vein endothelial cells (HUVEC). Only non-cytotoxic concentrations in HUVECs were used for the scratch assay. Metabolites 11, 12, 22, and 23 partially inhibited HUVEC migration at $20 \mu \mathrm{M}$ after $20 \mathrm{~h}$ of treatment (Figure 4), while in the tube formation assay, where HUVECs may form tube-like structures, no activity was observed for the tested compounds (data not shown). Thus, all tested steroids showed either little or no antiangiogenic activity. 

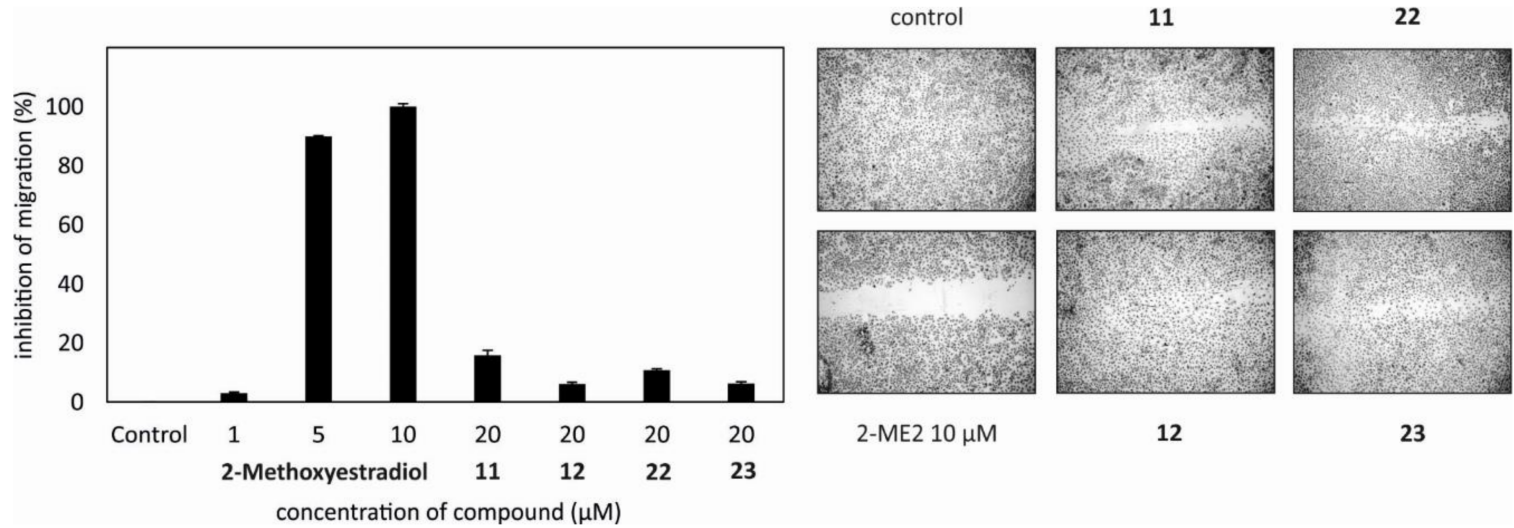

2-ME2 $10 \mu \mathrm{M}$

12

23

Figure 4. Compounds 11, 12, 22, and 23 inhibited migration of HUVECs after $20 \mathrm{~h}$ of treatment at $20 \mu \mathrm{M}$. 2-Methoxy-estradiol was used as a positive control. The experiment was repeated three times in triplicates.

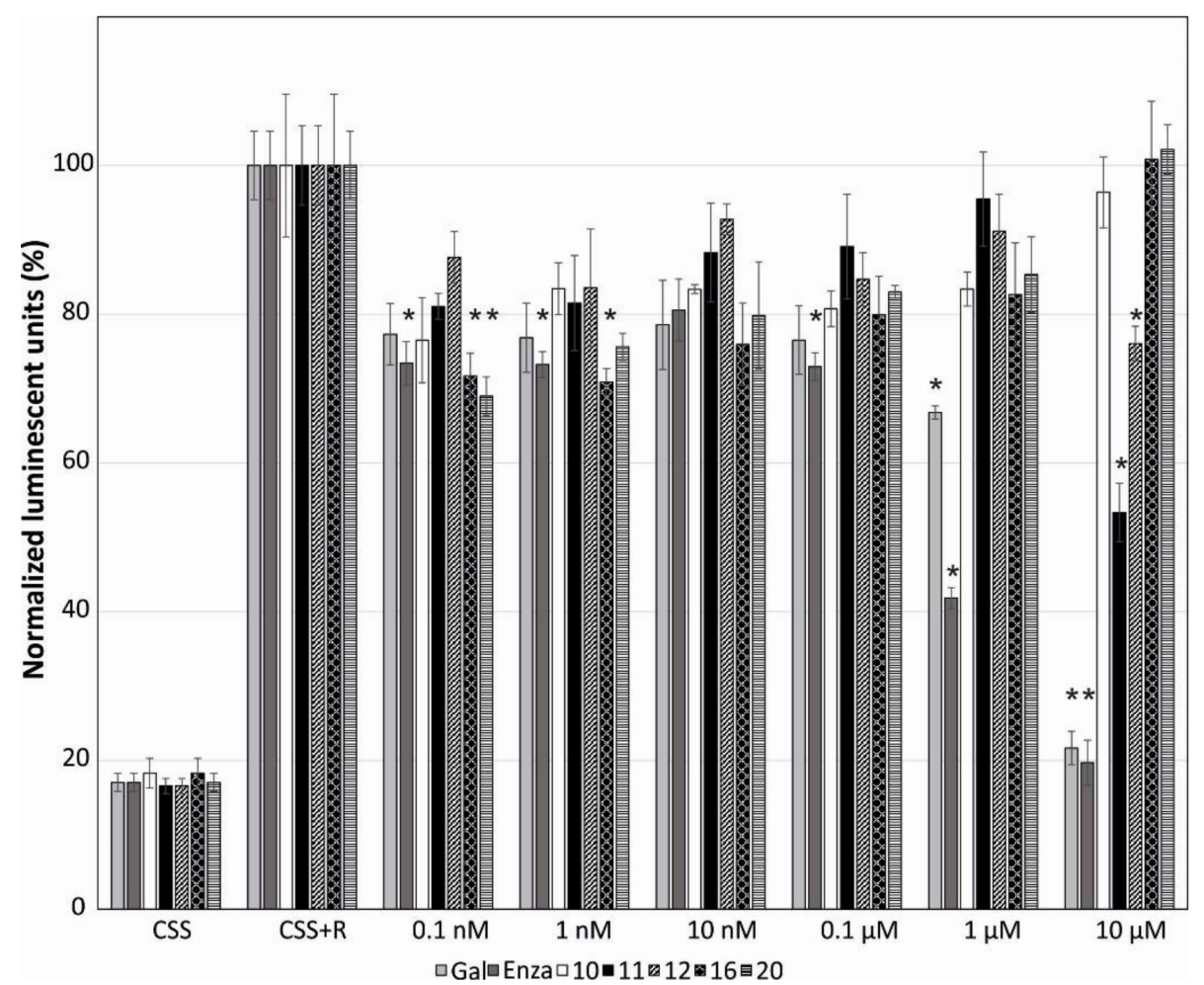

Figure 5. The influence of compounds 10, 11, 12, 16, and 20 on the androgen receptor-mediated transcription in the 22Rv1-ARE14 reporter cell line. Control cells were grown in charcoal-stripped serum medium (CSS). Cells were stimulated with either $1 \mathrm{nM}$ methyltrienolone R1881 (R) or with the tested compounds in six different concentrations for $24 \mathrm{~h}$ in CSS. The luciferase activity was measured in the cell lysate. Enzalutamide (Enza) and galeterone (Gal) were used as positive controls. The experiment was repeated three times in triplicates. Bars with asterisk $\left(^{*}\right)$ are significantly different from the control (CSS+R) based on Tukey's multiple comparison test $(p \leq 0.05)$.

The anti-inflammatory properties of metabolites 3-7, 9-12, 14-20, and 22-26 were determined by measuring the levels of endothelial leukocyte adhesion molecule-1 (ELAM/E-selectin), which is a key molecular marker in the initiation of inflammation, expressed on the cell surface. Cell adhesion molecules (ICAM-1, VCAM-1, E-selectin) are significantly increased on the vascular endothelium activated by pro-inflammatory mediators (tumor necrosis factor $\alpha$, TNF $\alpha$ ) as a crucial step for the extravasation of leukocytes into inflamed tissue [20]. TNF $\alpha$ stimulates NFkB (nuclear factor 
kappa-light-chain-enhancer of activated B cells) and thus E-selectin (CD62E, ELAM). Endothelial cells were pre-treated for 30 min with the tested compounds and then activated with TNF $\alpha$ for $4 \mathrm{~h}$. Curcumin, which inhibits activation of NF- $\kappa B$ and thus inhibits expression and activity of the COX-2 gene induced by $\mathrm{TNF} \alpha$ [21], was used as a positive control, decreasing ELAM production to $25 \%$ at $10 \mu \mathrm{M}$. None of the tested compounds decreased the levels of ELAM (Supplementary Materials Figure S1).

We have previously observed that several steroids with bulky or long side chains, such as galeterone derivatives or cholestanes, can also inhibit AR [22,23]. Therefore, we further analyzed the influence of the isolated steroids on AR-mediated transcription. Compounds 3-7, 9-12, 14-20, and 22-26 in six different concentrations were evaluated on the reporter cell line 22Rv1-ARE14 for $24 \mathrm{~h}$. Galeterone and enzalutamide, which were used as positive controls, showed a strong dose-dependent reduction of AR-regulated transcription ( $22 \%$ and $20 \%$ inhibition at $10 \mu \mathrm{M}$, respectively). Compounds $\mathbf{1 1}, \mathbf{1 2}, \mathbf{1 6}$, and 20 showed clearly reduced luciferase activity in a dose-dependent manner, already at submicromolar concentrations (Figure 5). The strongest inhibition of AR was displayed by compound 11 at $10 \mu \mathrm{M}$. Surprisingly, steroids 10, 16, and 20 showed increased inhibition of AR (or decreased the luciferase activity) with decreasing concentrations (Figure 5). All other steroids tested inhibited AR by no more than $20 \%$ (data not shown).
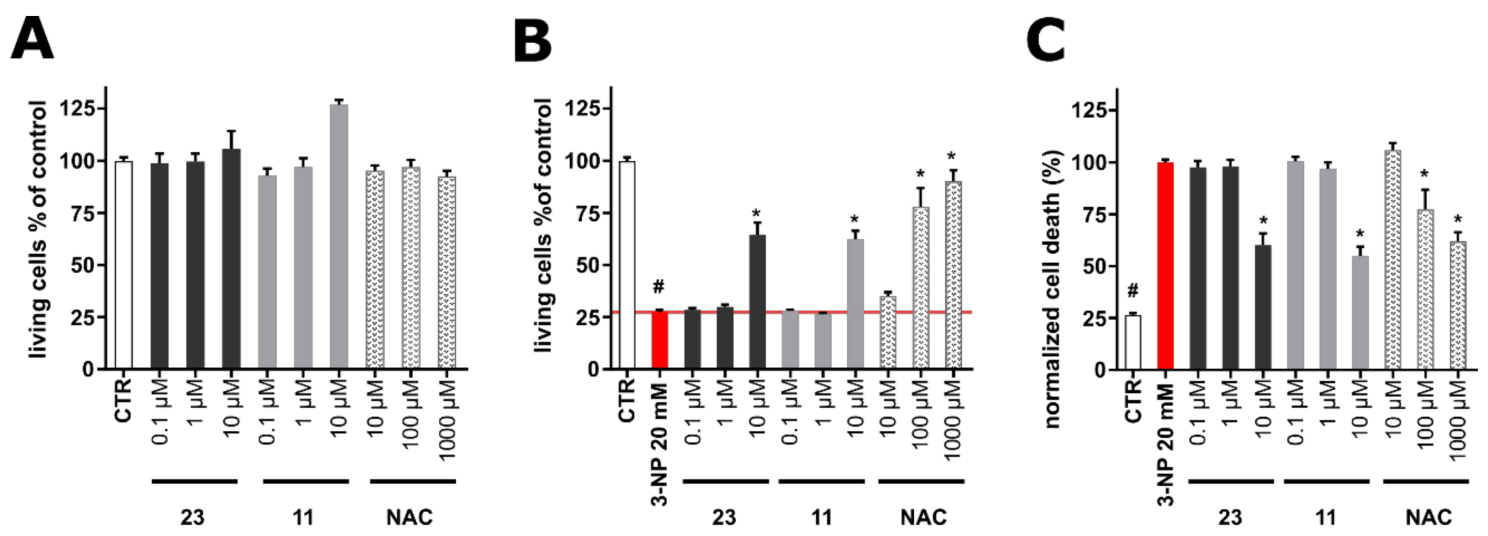

Figure 6. (A) Cytotoxicity of compounds $\mathbf{1 1}$ and $\mathbf{2 3}$ in human neuron-like SH-SY5Y cells after $48 \mathrm{~h}$ of treatment. All results are presented as mean \pm standard error of the mean (SEM) from at least three independent experiments in triplicates. (B) Neuroprotective activity of compounds $\mathbf{1 1}$ and 23 in the 3-nitropropionic acid (3-NPA)-induced model of Huntington's disease on human neuron-like SH-SY5Y cells after $48 \mathrm{~h}$ of treatment. (C) Cell death of neuron-like SH-SY5Y induced by 3-NPA and the protective effect of compounds $\mathbf{1 1}$ and $\mathbf{2 3}$ after $48 \mathrm{~h}$. The results are presented as mean \pm standard error of the mean (SEM) from triplicates in four independent experiments $(n=4)$. $N$-acetylcysteine (NAC) was used as a positive control. * $p$ compared with vehicle with $20 \mathrm{mM}$ 3-NPA, \# $p$ compared with vehicle without $20 \mathrm{mM} 3-\mathrm{NPA}$.

Since anti-androgens have shown neuroprotective effects in the in vivo model of Huntington's disease [24], selected compounds that showed cytotoxic activity and moderate activity in the migration scratch assay were tested for their cytotoxicity on differentiated human SH-SY5Y cells (neuron-like cells). Specifically, based on the combined results obtained for compounds 3-7, 9-12, 14-20, and 22-26 in the cytotoxicity assay, the anti-inflammatory activity assay, the migration scratch assay, and the tube formation assay in HUVECs, as well as in the reporter assay with AR, compounds $\mathbf{1 1}$ and 23 were selected as the two most active compounds that were subsequently evaluated for their neuroprotective activity. As shown in Figure 6A, compounds $\mathbf{1 1}$ and 23, as well as N-acetylcystein (NAC) that was used as a positive control, did not show cytotoxic, but rather stimulatory activity. In order to evaluate the potential neuroprotective effect of the compounds, neuroblastoma cell line SH-SY5Y was differentiated for $48 \mathrm{~h}$ and further exposed to $20 \mathrm{mM}$ 3-nitropropionic acid (3-NPA) 
as an agent mimicking Huntington's disease in vitro [25]. 3-NPA was used alone or in co-treatment with the tested compounds at concentrations of 0.1-10 $\mu \mathrm{M}$. As shown in Figure 6B, 3-NPA caused dramatic (approx. 70\%) decrease in cell viability determined by the Calcein AM assay. The positive control (NAC) showed partial (cell viability $77.9 \pm 8.99 \%$ at $100 \mu \mathrm{M}$ ) or almost complete (cell viability $90.2 \pm 5.28 \%$ at $1000 \mu \mathrm{M})$ protection of cells from the negative effect of 3-NPA. Compounds 11 and 23 showed significant protective effects at $10 \mu \mathrm{M}$ (cell viability $64.4 \pm 6.02 \%$ for 11 and $62.5 \pm 3.95 \%$ for 23), comparable to $100 \mu \mathrm{M}$ of the positive control NAC. Being encouraged by the promising results, we further analyzed the protective effects of $\mathbf{1 1}$ and $\mathbf{2 3}$ using an orthogonal method (propidium iodide (PI) assay) to verify their activity. In general, PI as a positively charged dye is associated with an increase of cell damage or death, since it penetrates cells with cell-disrupted membranes [26]. Within the 3-NPA model, its toxic effect was considered as $100 \%$ of the PI signal and thus reduction of cell death was determined. As shown in Figure 6C, compounds $\mathbf{1 1}$ and $\mathbf{2 3}$ significantly reduced cell death (maximal effect at $10 \mu \mathrm{M})$ in a manner similar to NAC $(100 \mu \mathrm{M}, 77.2 \pm 9.53 \% ; 1000 \mu \mathrm{M}$, $62.1 \pm 4.19 \%$ ), thus confirming the protective effects of $\mathbf{1 1}$ and $\mathbf{2 3}$ observed in the viability assay.

\section{Materials and Methods}

\subsection{General Experimental Procedures}

Optical rotations were measured on a Krüss polarimeter (A. KRÜSS Optronic GmbH, Hamburg, Germany) equipped with a $0.5 \mathrm{dm}$ cell. UV spectra were recorded on a Lambda $40 \mathrm{UV} / \mathrm{Vis}$ spectrophotometer (Perkin Elmer Ltd., Beaconsfield, UK). IR spectra were obtained on an Alpha II FTIR spectrometer (Bruker Optik GmbH, Ettlingen, Germany). Low-resolution EI mass spectra were measured on a Thermo Electron Corporation DSQ mass spectrometer (Thermo Fisher Scientific, Bremen, Germany). High-resolution APCI or ESI mass spectra were measured on a LTQ Orbitrap Velos mass spectrometer (Thermo Fisher Scientific, Bremen, Germany). NMR spectra were recorded on Bruker AC 200, DRX 400, and Avance NEO 950 (Bruker BioSpin GmbH, Rheinstetten, Germany) and Varian 600 (Varian, Inc., Palo Alto, CA, USA) spectrometers. Chemical shifts are given on the $\delta$ (ppm) scale with reference to the solvent signals. The 2D NMR experiments (HSQC, HMBC, COSY, NOESY) were performed using standard Bruker or Varian pulse sequences. Column chromatography separations were performed with Kieselgel 60 (Merck, Darmstadt, Germany). HPLC separations were conducted on a Waters 600 liquid chromatography pump equipped with a Waters 410 differential refractometer (Waters Corporation, Milford, MA, USA), using a Kromasil $100 \mathrm{C}_{18}(25 \mathrm{~cm} \times 8 \mathrm{~mm}$ i.d.) column (MZ-Analysentechnik GmbH, Mainz, Germany). TLC were performed with Kieselgel $60 \mathrm{~F}_{254}$ aluminum plates (Merck, Darmstadt, Germany) and spots were detected after spraying with 25\% $\mathrm{H}_{2} \mathrm{SO}_{4}$ in $\mathrm{MeOH}$ reagent and heating at $100{ }^{\circ} \mathrm{C}$ for $1 \mathrm{~min}$.

\subsection{Biological Material}

Specimens of $S$. polydactyla were hand-picked by SCUBA diving at a depth of $10 \mathrm{~m}$ from the reefs near the National Institute of Oceanography and Fisheries (NOIF), Hurghada, Egypt (GPS coordinates $27^{\circ} 17^{\prime} 06^{\prime \prime} \mathrm{N}, 33^{\circ} 46^{\prime} 24^{\prime \prime} \mathrm{E}$ ) in June 2015 and transported to the laboratory in ice chests, where they were stored at $-20^{\circ} \mathrm{C}$ until analyzed. A voucher specimen has been deposited at the animal collection of NOIF in Hurghada and the animal collection of the Section of Pharmacognosy and Chemistry of Natural Products, Department of Pharmacy, National and Kapodistrian University of Athens (ATPH/MP0533).

\subsection{Extraction and Isolation}

Specimens of the freeze-dried gorgonian (119.9 g) were exhaustively extracted with mixtures of $\mathrm{CH}_{2} \mathrm{Cl}_{2} / \mathrm{MeOH}(2: 1)$ at room temperature. Evaporation of the solvents under vacuum afforded a dark green residue (18.5 g) which was submitted to vacuum column chromatography on silica gel using cHex with increasing amounts of EtOAc followed by EtOAc with increasing amounts of $\mathrm{MeOH}$ as eluent to yield 9 fractions (A-I). Fraction B (2.5 g, 30-50\% EtOAc in cHex) was fractionated by vacuum 
column chromatography on silica gel using mixtures of cHex/EtOAc of increasing polarity as mobile phase to yield 6 fractions (B1-B6). Fraction B6 (0.5 g, 20-30\% EtOAc in cHex) was further fractionated by gravity column chromatography on silica gel using mixtures of cHex/EtOAc of increasing polarity as mobile phase to afford 10 fractions (B6a-B6j). Fractions B6e, B6g, and B6h were subjected repeatedly to reversed-phase $\mathrm{HPLC}$, using $\mathrm{MeOH} / \mathrm{H}_{2} \mathrm{O}$ (100:0 and 98:2) as eluent to yield compounds 3 (9.9 mg), $\mathbf{4}(8.8 \mathrm{mg}), \mathbf{5}(1.8 \mathrm{mg}), \mathbf{6}(5.9 \mathrm{mg}), \mathbf{8}(0.8 \mathrm{mg})$, and $\mathbf{1 7}(14.0 \mathrm{mg})$. Fraction C (2.5 g, 60-70\% EtOAc in cHex) was submitted to vacuum column chromatography on silica gel using mixtures of cHex/EtOAc of increasing polarity as mobile phase to afford 9 fractions (C1-C9). Fractions $\mathrm{C} 5, \mathrm{C} 6, \mathrm{C} 7$, and $\mathrm{C} 8$ were subjected repeatedly to reversed-phase HPLC using $\mathrm{MeOH} / \mathrm{H}_{2} \mathrm{O}(100: 0,98: 2$, and 97:3) as eluent to afford compounds $\mathbf{1}(0.7 \mathrm{mg}), \mathbf{2}(0.3 \mathrm{mg}), \mathbf{7}(6.3 \mathrm{mg}), \mathbf{9}(5.7 \mathrm{mg})$, and $\mathbf{1 0}(5.7 \mathrm{mg})$. Fraction D $(0.9 \mathrm{~g}$, $80-90 \%$ EtOAc in cHex) was fractionated by gravity column chromatography on silica gel using cHex with increasing amounts of $\mathrm{Me}_{2} \mathrm{CO}$ as mobile phase to afford 18 fractions (D1-D18). Fractions D8, D9, D11, and D12 were subjected repeatedly to reversed-phase HPLC using $\mathrm{MeOH} / \mathrm{H}_{2} \mathrm{O}$ (100:0 and 98:2) as eluent to yield compounds $\mathbf{1 1}(4.0 \mathrm{mg}), \mathbf{1 2}(2.2 \mathrm{mg}), \mathbf{1 3}(1.3 \mathrm{mg}), \mathbf{1 4}(1.1 \mathrm{mg}), \mathbf{1 5}(9.4 \mathrm{mg})$, and $\mathbf{1 6}(2.3 \mathrm{mg})$. Fraction $\mathrm{E}(0.23 \mathrm{~g}, 100 \% \mathrm{EtOAc})$ was fractionated by gravity column chromatography on silica gel using cHex with increasing amounts of $\mathrm{Me}_{2} \mathrm{CO}$ as mobile phase to afford 10 fractions (E1-E10). Fractions E3, E5, and E6 were subjected repeatedly to reversed-phase HPLC using mixtures of $\mathrm{MeOH} / \mathrm{H}_{2} \mathrm{O}(100: 0$ and 97:3) as eluent to yield compounds $18(1.7 \mathrm{mg}), \mathbf{1 9}(17.5 \mathrm{mg}), 20(2.0 \mathrm{mg}), 22(2.1 \mathrm{mg})$, and 23 $(1.0 \mathrm{mg})$. Fraction $\mathrm{G}(1.7 \mathrm{~g}, 50 \% \mathrm{MeOH}$ in EtOAc) was separated by vacuum column chromatography on silica gel using cHex with increasing amounts of EtOAc and EtOAc with increasing amounts of $\mathrm{MeOH}$ to yield 7 fractions (G1-G7). Fractions G5 and G7 were subjected repeatedly to reversed-phase HPLC using $\mathrm{MeOH} / \mathrm{H}_{2} \mathrm{O}$ (100:0 and 97:3) as eluent to yield compounds $24(6.9 \mathrm{mg}), 25(2.0 \mathrm{mg})$, and 26 ( $3.1 \mathrm{mg})$. Fraction I ( $5.1 \mathrm{~g}, 100 \% \mathrm{MeOH})$ was subjected to vacuum column chromatography on silica gel using cHex with increasing amounts of EtOAc followed by EtOAc with increasing amounts of $\mathrm{MeOH}$ to afford 11 fractions (I1-I11). Fractions I6 and I7 were combined and subjected repeatedly to reversed-phase HPLC using $\mathrm{MeOH}(100 \%)$ as eluent to yield compound 21 (2.3 mg).

(9E,22E,24R)-3 $\beta$-Hydroxy-4 $\alpha$,24-dimethyl-8,9-seco-5 $\alpha$-cholesta-9(11),22-dien-8-one (1): White amorphous solid; ${ }^{1} \mathrm{H}$ and ${ }^{13} \mathrm{C}$ NMR data, see Tables 1 and 2; HR-APCIMS $\mathrm{m} / z 429.3724[\mathrm{M}+\mathrm{H}]^{+}$(calcd. for $\mathrm{C}_{29} \mathrm{H}_{49} \mathrm{O}_{2}$, 429.3727).

(9E)-3 $\beta$-Hydroxy-4 $\alpha$,24-dimethyl-8,9-seco-5 $\alpha$-cholesta-9(11),24(28)-dien-8-one (2): White amorphous solid; ${ }^{1} \mathrm{H}$ NMR data, see Table 1 ; HR-APCIMS $m / z 429.3725[\mathrm{M}+\mathrm{H}]^{+}$(calcd. for $\mathrm{C}_{29} \mathrm{H}_{49} \mathrm{O}_{2}, 429.3727$ ).

(22E,24R)-4 $\alpha$,24-Dimethyl- $5 \alpha$-cholest-22-en-3 $\beta, 8 \beta$-diol (6): White amorphous solid; $[\alpha]_{\mathrm{D}}^{20}+68$ (c 0.25, $\mathrm{CHCl}_{3}$ ); UV $\left(\mathrm{CHCl}_{3}\right) \lambda_{\max }(\log \varepsilon) 206$ (2.85); IR (thin film) $v_{\max }$ 3440, 2954, 2856, 1466, 1384, $964 \mathrm{~cm}^{-1} ;{ }^{1} \mathrm{H}$ and ${ }^{13} \mathrm{C}$ NMR data, see Tables 1 and 2; HR-APCIMS $m / z 413.3773\left[\mathrm{M}-\mathrm{H}_{2} \mathrm{O}+\mathrm{H}\right]^{+}$(calcd. for $\mathrm{C}_{29} \mathrm{H}_{49} \mathrm{O}, 413.3778$ ).

(23E)-22 $\alpha, 28$-Epidioxy-4 $\alpha, 24$-dimethyl-5 $\alpha$-cholest-23-en-3 $\beta, 8 \beta$-diol (8): White amorphous solid; $[\alpha]_{\mathrm{D}}^{20}-50\left(c \quad 0.02, \mathrm{CHCl}_{3}\right) ; \mathrm{UV}\left(\mathrm{CHCl}_{3}\right) \lambda_{\max }(\log \varepsilon) 206$ (3.94), 225 (3.84); IR (thin film) $v_{\max } 3458,2927$, 2861, 1723, 1462, 1378, 1243, $1013 \mathrm{~cm}^{-1} ;{ }^{1} \mathrm{H}$ and ${ }^{13} \mathrm{C}$ NMR data, see Tables 1 and 2; HR-APCIMS $\mathrm{m} / \mathrm{z}$ $459.3475[\mathrm{M}-\mathrm{H}]^{-}$(calcd. for $\mathrm{C}_{29} \mathrm{H}_{47} \mathrm{O}_{4}, 459.3480$ ).

(23E)-22 $\alpha, 28$-Epidioxy-4 $\alpha, 24$-dimethyl-5 $\alpha$-cholest-23-en-3 $\beta, 8 \beta, 11 \beta$-triol (13): White amorphous solid; $[\alpha]_{\mathrm{D}}^{20}+30\left(c 0.1, \mathrm{CHCl}_{3}\right) ; \mathrm{UV}\left(\mathrm{CHCl}_{3}\right) \lambda_{\max }(\log \varepsilon) 206$ (3.26), 230 (2.97); IR (thin film) $v_{\max } 3403$, 2923, 2873, 1725, 1450, 1377, 1261, $1045 \mathrm{~cm}^{-1} ;{ }^{1} \mathrm{H}$ and ${ }^{13} \mathrm{C}$ NMR data, see Tables 1 and 2; HR-APCIMS $m / z 475.3424[\mathrm{M}-\mathrm{H}]^{-}$(calcd. for $\mathrm{C}_{29} \mathrm{H}_{47} \mathrm{O}_{5}, 475.3429$ ).

(22E)-24-Methyl-cholesta-5,22,24(28)-trien-3 $\beta, 19$-diol (20): White amorphous solid; $[\alpha]_{\mathrm{D}}^{20}-133$ (c 0.03, $\mathrm{CHCl}_{3}$ ); UV $\left(\mathrm{CHCl}_{3}\right) \lambda_{\max }(\log \varepsilon) 206$ (3.61), 232 (3.76); IR (thin film) $v_{\max } 3433,2919,2857,1462$, 1377, 1261, $1037 \mathrm{~cm}^{-1} ;{ }^{1} \mathrm{H}$ and ${ }^{13} \mathrm{C}$ NMR data, see Tables 1 and 2; HR-ESIMS $\mathrm{m} / z$ 411.3271 [M - H] $]^{-}$ (calcd. for $\mathrm{C}_{28} \mathrm{H}_{43} \mathrm{O}_{2}, 411.3269$ ). 


\subsection{Cell Culture}

The tested compounds were dissolved in DMSO to afford $10 \mathrm{mM}$ stock solutions. Human cervical carcinoma (HeLa) and human breast adenocarcinoma (MCF7) cell lines were purchased from European Collection of Authenticated Cell Cultures (ECACC, Salisbury, UK) and cultivated in Dulbecco's Modified Eagle Medium (DMEM) (Merck, Darmstadt, Germany), as previously reported [27]. Human umbilical vein endothelial cells (HUVECs) were a kind gift of Prof. Jitka Ulrichová (Faculty of Medicine and Dentistry, Palacky University, Olomouc, Czech Republic). The cultivation and assay was performed in endothelial cell proliferation medium (ECPM, Provitro, Berlin, Germany) [23]. The 22Rv1-ARE14 reporter cell line [28] was a generous gift of Prof. Zdeněk Dvořák (Department of Cell Biology and Genetics, Palacky University). The 22Rv1-ARE14 cell line was grown in Roswell Park Memorial Institute 1640 Medium (RPMI 1640) [22]. All cells were maintained in a humidified $\mathrm{CO}_{2}$ incubator at $37^{\circ} \mathrm{C}$ using the standard trypsinization procedure twice or three times a week. The SH-SY5Y human neuroblastoma cell line (ECACC, Salisbury, UK) was cultivated in DMEM and Ham's F12 Nutrient Mixture (DMEM:F12, 1:1), as previously described [25]. Cells were used up to twenty passages. All trans-retinoic acid $(10 \mu \mathrm{M})$ in 1\% FBS DMEM/F12 medium was added to SH-SY5Y cells to achieve differentiation conditions [29,30], to reach longer neurites and reduced proliferation (48 h). All cells were maintained in a humidified $\mathrm{CO}_{2}$ incubator at $37^{\circ} \mathrm{C}$ using the standard trypsinization procedure twice or three times a week.

\subsection{Evaluation of Cytotoxicity}

In cytotoxicity assays, cancer cells were treated with six different concentrations of each tested compound for $72 \mathrm{~h}$. Cells were stained with resazurin and $\mathrm{IC}_{50}$ values were calculated as previously reported [26]. Triplicates from at least three independent experiments were used. For the ELAM assay, the Calcein AM (Molecular Probes, Invitrogen, Karlsruhe, Germany) cytotoxicity assay, which assessed HUVEC viability after $4 \mathrm{~h}$ treatment, was used as previously described [31].

\subsection{Cell-Surface ELISA CD62E (E-Selectin, ELAM)}

An enzyme-linked immunosorbent assay (ELISA) was used to detect the levels of the cell adhesion molecule ELAM in HUVEC cells after 30 min of incubation with the tested compounds and $4 \mathrm{~h}$ of stimulation with $\mathrm{TNF} \alpha$, as previously described [31].

\subsection{Migration Scratch Assay}

The scratch test was performed with HUVEC cells and evaluated after $20 \mathrm{~h}$ of treatment, as previously reported [23].

\subsection{AR-Transcriptional Reporter Assay}

AR-transcriptional reporter assays were performed on 22Rv1-ARE14 cells after $24 \mathrm{~h}$ of incubation, as previously described [22].

\subsection{SH-SY5Y Cell Treatments and Evaluation of Cell Viability/Cytotoxicity}

Cell viability of neuron-like SH-SY5Y cells growing in 96-well plates (7000 cells/well) $24 \mathrm{~h}$ after treatment was evaluated using the Calcein AM assay [27], with minor modification of Calcein AM concentration $(0.75 \mu \mathrm{M})$. Cell death of SH-SY5Y cells $(20,000$ cells/well) was determined using the propidium iodide (PI) assay according to Stone et al. with a slight modification [32]. Briefly, PI solution in PBS is added to cell medium to reach concentration $1 \mu \mathrm{g} / \mathrm{mL}$, incubated for $15 \mathrm{~min}$ at room temperature and quantified at 535/617 nm (excitation/emission) by Infinite M200 Pro reader (Tecan, Austria). The resulting fluorescence of 3-NPA toxin was considered as $100 \%$ cell death. In the assays, neuron-like cells were treated with the tested compounds in $0.1-10 \mu \mathrm{M}$ concentration range for $48 \mathrm{~h}$. DMSO-treated cells $(\leq 0.1 \% v / v)$ were used as healthy controls. 


\subsection{Statistical Analysis}

All data are expressed as mean \pm SD or SEM. Data were evaluated by non-parametric Kruskal-Wallis test followed by post-hoc Mann-Whitney test (Figure 6) with sequential Bonferroni correction of $p$-values or ANOVA followed by Tukey's multiple comparison test (Figure 5) using the PAST (version 1.97) software package [33]. $p$-values $<0.05$ were considered statistically significant.

\section{Conclusions}

The chemical analysis of the organic extract of the soft coral S. polydactyla collected from the Hurghada reef in the Red Sea resulted in the isolation of 26 steroids, with six of them $(\mathbf{1}, \mathbf{2}, \mathbf{6}, \mathbf{8}$, 13, and 20) being new natural products. Among them, 1 and 2 display the rare 8,9-seco-cholestane steroidal nucleus. To the best of our knowledge, dictyoneolone, isolated from a sponge of the genus Dictyonella, is the only previously reported 4-methyl-8,9-seco-cholestane derivative [34]. Evaluation of cytotoxic, anti-inflammatory, anti-angiogenic, and neuroprotective activity of the majority of the isolated metabolites that were isolated in adequate quantities revealed significant cytotoxicity in the low micromolar range against the HeLa and MCF7 cancer cell lines for compounds 22 and 23, while compounds 11, 12, 22, and 23 inhibited the migration of endothelial cells at $20 \mu \mathrm{M}$. Most of the compounds with activity against cancer cells also showed cytotoxicity toward normal cells (BJ), except for compounds 11, 12, 14, 15, and 18. Compared to cisplatin, these compounds have therefore a broad therapeutic window due to low or zero cytotoxicity on normal human fibroblasts. Moreover, metabolite 22 was more active against HeLa cells than cisplatin used as positive control. Furthermore, the effect of the isolated metabolites on AR-regulated transcription was evaluated in vitro in human tumor and non-cancerous cells, with compound 11 exhibiting the strongest inhibition of AR at $10 \mu \mathrm{M}$. It is worth-noting that metabolites 10, 16, and 20 displayed increased inhibition of AR with decreasing concentrations. In addition, compounds $\mathbf{1 1}$ and $\mathbf{2 3}$ showed neuroprotective activity on neuron-like SH-SY5Y cells.

Supplementary Materials: The following are available online at http://www.mdpi.com/1660-3397/18/12/632/s1. Figure S1: Visual representation of the evaluation of the activity of the tested metabolites against ELAM. Figures S2-S29: 1D and 2D NMR and HR-MS spectra of compounds 1, 2, 6, 8, 13, and 20.

Author Contributions: Conceptualization, M.S., E.I., and V.R.; methodology, L.R., M.K., G.G., M.S., E.I., and V.R.; formal analysis, M.A.T., L.R., and E.I.; investigation, M.A.T., L.R., M.K., G.G., A.M., M.S., E.I., and V.R.; resources, M.S., E.I., and V.R.; writing-original draft preparation, M.A.T., L.R., M.K., G.G., and E.I.; writing-review and editing, L.R., A.M.E., M.S., E.I., and V.R.; visualization, M.A.T., L.R., and E.I.; supervision, M.S., E.I., and V.R.; project administration, M.S., E.I., and V.R.; funding acquisition, M.S., E.I., and V.R. All authors have read and agreed to the published version of the manuscript.

Funding: This work was supported by the research projects MARINOVA (grant number 70/3/14684, V.R.) and BioNP (grant number 70/3/14685, E.I.). Biological activity evaluation was supported by the grants of Czech Science Foundation 19-01383S, 20-15621S and IGA_PrF_2020_021.

Acknowledgments: M.A.T. acknowledges support by the mission sector of the Ministry of Higher Education of the Arab Republic of Egypt (Egyptian Cultural Bureau in Athens), the Directorate of Education and Cultural Affairs, Ministry of Foreign Affairs of Greece and the non-profit organization "Kleon Tsetis". We thank Jitka Ulrichová for the kind gift of HUVEC cells and Zdeněk Dvořák for the kind gift of 22Rv1-ARE14 cells. Authors also thank Anežka Šindlerová and Veronika Górová for excellent technical assistance. Assistance on the acquisition of some NMR data by Lukasz Jaremko (King Abdullah University of Science and Technology, Saudi Arabia) is gratefully acknowledged.

Conflicts of Interest: The authors declare no conflict of interest. The funders had no role in the design of the study; in the collection, analyses, or interpretation of data; in the writing of the manuscript, or in the decision to publish the results. 


\section{References}

1. Kotb, M.M.A.; Hanafy, M.H.; Rirache, H.; Matsumura, S.; Al-Sofyani, A.A.; Ahmed, A.G.; Bawazir, G.; Al-Horani, F.A. Status of coral reefs in the Red Sea and Gulf of Aden region. In Status of Coral Reefs of the World: 2008; Wilkinson, C., Ed.; Global Coral Reef Monitoring Network and Reef and Rainforest Research Centre: Townsville, Australia, 2008; pp. 67-78.

2. Carroll, A.R.; Copp, B.R.; Davis, R.A.; Keyzers, R.A.; Prinsep, M.R. Marine natural products. Nat. Prod. Rep. 2020, 37, 175-223. [CrossRef] [PubMed]

3. MarinLit. A Database of the Marine Natural Products Literature. Available online: http://pubs.rsc.org/ marinlit/ (accessed on 30 September 2020).

4. Končić, M.; Ioannou, E.; Sawadogo, W.; Abdel-Razik, A.; Vagias, C.; Diederich, M.; Roussis, V. 4a-Methylated steroids with cytotoxic activity from the soft coral Litophyton mollis. Steroids 2016, 115, 130-135. [CrossRef] [PubMed]

5. Yu, S.; Deng, Z.; van Ofwegen, L.; Proksch, P.; Lin, W. 5,8-Epidioxysterols and related derivatives from a Chinese soft coral Sinularia flexibilis. Steroids 2006, 71, 955-959. [CrossRef] [PubMed]

6. Kokke, W.; Bohlin, L.; Fenical, W.; Djerassi, C. Novel dinoflagellate $4 \alpha$-methylated sterols from four caribbean gorgonians. Phytochemistry 1982, 21, 881-887. [CrossRef]

7. Kobayashi, M.; Ishizaka, T.; Mitsuhashi, H. Marine sterols X. Minor constituents of the sterols of the soft coral Sarcophyton glaucum. Steroids 1982, 40, 209-221. [CrossRef]

8. Mehta, G.; Venkateswarlu, Y.; Rama, R.M.; Uma, R. A novel $4 \alpha$-methyl sterol from the soft coral Nephthea chabroli. J. Chem. Res. 1999, 23, 628-629. [CrossRef]

9. Bortolotto, M.; Braekman, J.; Daloze, D.; Tursch, B. Chemical studies of marine invertebrates. XXIX. $4 \alpha$-methyl-3 $\beta, 8 \beta$-dihydroxy- $5 \alpha$-ergost-24(28)-en-23-one, a novel polyhydroxygenated sterol from the soft coral litophyton viridis. Steroids 1977, 30, 159-164. [CrossRef]

10. Cheng, S.; Huang, Y.; Wen, Z.; Hsu, C.; Wang, S.; Dai, C.; Duh, C. New 19-oxygenated and 4-methylated steroids from the formosan soft coral Nephthea chabroli. Steroids 2009, 74, 543-547. [CrossRef]

11. Huang, Y.; Wen, Z.; Wang, S.; Hsu, C.; Duh, C. New anti-inflammatory 4-methylated steroids from the formosan soft coral Nephthea chabroli. Steroids 2008, 73, 1181-1186. [CrossRef]

12. Viegelmann, C.; Parker, J.; Ooi, T.; Clements, C.; Abbott, G.; Young, L.; Kennedy, J.; Dobson, A.; Edrada-Ebel, R. Isolation and identification of antitrypanosomal and antimycobacterial active steroids from the sponge Haliclona simulans. Mar. Drugs 2014, 12, 2937-2952. [CrossRef]

13. Riccardis, F.; Minale, L. Marine sterols side-chain-oxygenated sterols, possibly of abiotic origin, from the new caledonian sponge stelodoryx chlorophylla. J. Nat. Prod. 1993, 56, 282-287. [CrossRef]

14. Iguchi, K.; Saitou, S.; Yamada, Y. Novel 19-oxygenated sterols from the okinawan soft coral Litophyton viridis. Chem. Pharm. Bull. 1989, 37, 2553-2554. [CrossRef]

15. Cheng, S.; Dai, C.; Duh, C. New 4-methylated and 19-oxygenated steroids from the formosan soft coral Nephthea erecta. Steroids 2007, 72, 653-659. [CrossRef] [PubMed]

16. Ellithey, M.; Lall, N.; Hussein, A.; Meyer, D. Cytotoxic, cytostatic and HIV-1 PR inhibitory activities of the soft coral Litophyton arboretum. Mar. Drugs 2013, 11, 4917-4936. [CrossRef]

17. Duh, C.; Wang, S.; Chu, M.; Sheu, J. Cytotoxic sterols from the soft coral Nephthea erecta. J. Nat. Prod. 1998, 61, 1022-1024. [CrossRef]

18. Iorizzi, M.; Minale, L.; Riccio, R. Polar steroids from the marine scallop Patinopecten yessoensis. J. Nat. Prod. 1988, 51, 1098-1103. [CrossRef]

19. Sattler, M.; Quinnan, L.R.; Pride, Y.B.; Gramlich, J.L.; Chu, S.C.; Even, G.C.; Kraeft, S.-K.; Chen, L.B.; Salgia, R. 2-Methoxyestradiol alters cell motility, migration, and adhesion. Blood 2003, 102, 289-296. [CrossRef]

20. Trepels, T.; Zeiher, A.M.; Fichtlscherer, S. The endothelium and inflammation. Endothelium 2006, 13, 423-429. [CrossRef]

21. Zhang, F.; Altorki, N.K.; Mestre, J.R.; Subbaramaiah, K.; Dannenberg, A.J. Curcumin inhibits cyclooxygenase-2 transcription in bile acid- and phorbol ester-treated human gastrointestinal epithelial cells. Carcinogenesis 1999, 20, 445-451. [CrossRef]

22. Jorda, R.; Řezníčková, E.; Kiełczewska, U.; Maj, J.; Morzycki, J.W.; Siergiejczyk, L.; Bazgier, V.; Berka, K.; Rárová, L.; Wojtkielewicz, A. Synthesis of novel galeterone derivatives and evaluation of their in vitro activity against prostate cancer cell lines. Eur. J. Med. Chem. 2019, 179, 483-492. [CrossRef] 
23. Rárová, L.; Sedlák, D.; Oklestkova, J.; Steigerová, J.; Liebl, J.; Zahler, S.; Bartůněk, P.; Kolář, Z.; Kohout, L.; Kvasnica, M.; et al. The novel brassinosteroid analog BR4848 inhibits angiogenesis in human endothelial cells and induces apoptosis in human cancer cells in vitro. J. Steroid Biochem. Mol. Biol. 2018, 178, $263-271$.

24. Calderon Guzman, D.; Bratoeff, E.; Chávez-Riveros, A.; Osnaya, N.; Barragan, G.; Hernandez Garcia, E.; Olguín, H.; Garcia, E. Effect of two antiandrogens as protectors of prostate and brain in a Huntington's animal model. Anticancer Agents Med. Chem. 2014, 14, 1293-1301. [CrossRef] [PubMed]

25. Colle, D.; Santos, D.; Hartwig, J.; Godoi, M.; Engel, D.; de Bem, A.; Braga, A.; Farina, M. Succinobucol, a lipid-lowering drug, protects against 3-nitropropionic acid-induced mitochondrial dysfunction and oxidative stress in SH-SY5Y cells via upregulation of glutathione levels and glutamate cysteine ligase activity. Mol. Neurobiol. 2016, 53, 1280-1295. [CrossRef] [PubMed]

26. Dengler, W.A.; Schulte, J.; Berger, D.P.; Mertelsmann, R.; Fiebig, H.H. Development of a propidium iodide fluorescence assay for proliferation and cytotoxicity assays. Anticancer Drugs 1995, 6, 522-532. [CrossRef]

27. Rárová, L.; Steigerová, J.; Kvasnica, M.; Bartůněk, P.; Křížová, K.; Chodounská, H.; Kolář, Z.; Sedlák, D.; Oklestkova, J.; Strnad, M. Structure activity relationship studies on cytotoxicity and the effects on steroid receptor of AB-functionalized cholestanes. J. Steroid Biochem. Mol. Biol. 2016, 159, 154-169. [CrossRef]

28. Bartonkova, I.; Novotna, A.; Dvorak, Z. Novel stably transfected human reporter cell line AIZ-AR as a tool for an assessment of human androgen receptor transcriptional activity. PLoS ONE 2015, 10, e0121316. [CrossRef]

29. Cheung, Y.-T.; Lau, W.K.-W.; Yu, M.-S.; Lai, C.S.-W.; Yeung, S.-C.; So, K.-F.; Chang, R.C.-C. Effects of all-trans-retinoic acid on human SH-SY5Y neuroblastoma as in vitro model in neurotoxicity research. Neurotoxicology 2009, 30, 127-135. [CrossRef]

30. Dwane, S.; Durack, E.; Kiely, P.A. Optimising parameters for the differentiation of SH-SY5Y cells to study cell adhesion and cell migration. BMC Res. Notes 2013, 6, 366. [CrossRef]

31. Morrogh-Bernard, H.C.; Foitová, I.; Yeen, Z.; Wilkin, P.; de Martin, R.; Rárová, L.; Doležal, K.; Nurcahyo, W.; Olšanský, M. Self-medication by orang-utans (Pongo pygmaeus) using bioactive properties of Dracaena cantleyi. Sci. Rep. 2017, 7, 16653. [CrossRef]

32. Stone, W.L.; Qui, M.; Smith, M. Lipopolysaccharide enhances the cytotoxicity of 2-chloroethyl ethyl sulfide. BMC Cell Biol. 2003, 4, 1. [CrossRef]

33. Hammer, O.; Harper, D.A.T.; Ryan, P.D. PAST: Paleontological statistics software package for education and data analysis. Palaeontol. Electron. 2001, 4, 9.

34. Woo, J.-K.; Yun, J.-H.; Ahn, S.; Sim, C.J.; Noh, M.; Oh, D.-C.; Oh, K.-B.; Shin, J. Dictyoneolone, a B/C ring juncture-defused steroid from a Dictyonella sp. sponge. Tetrahedron Lett. 2018, 59, 2021-2024. [CrossRef]

Publisher's Note: MDPI stays neutral with regard to jurisdictional claims in published maps and institutional affiliations.

(C) 2020 by the authors. Licensee MDPI, Basel, Switzerland. This article is an open access article distributed under the terms and conditions of the Creative Commons Attribution (CC BY) license (http://creativecommons.org/licenses/by/4.0/). 